Acta Regionalia et Environmentalica 2

Nitra, Slovaca Universitas Agriculturae Nitriae, 2015, pp. 47-51

\title{
BIOGAS PRODUCTION BASED ON MISCANTHUS $\times$ GIGANTEUS (MISCANTHUS SINENSIS ANDERSS.) WITHIN DRY FERMENTATION PROCESS
}

\author{
Pavol PORVAZ ${ }^{* *}$, Ján GADUŠ², Štefan TÓTH', János JÓVÉR ${ }^{3}$ \\ ${ }^{1}$ National Agricultural and Food Centre, Agroecology research Institute in Michalovce, Slovak Republic \\ ${ }^{2}$ Slovak University of Agriculture in Nitra, Slovak Republic \\ ${ }^{3}$ Debreceni Egytelem, Agrártudományi Központ, Karcagi Kutatóinvézet, Hungary
}

\begin{abstract}
"Dry fermentation" technology may be used for energy recovery of phytomass substrate which has dry matter content from 20 to $60 \%$. In agriculture sector, while only rarely used, it is a very perspective technology at such types of biomass - phytomass which is not recommended to be processed within "wet fermentation" (process is energetically and operationally very costly). For detecting the suitability of Miscanthus $\times$ giganteus phytomass to biogas for production through dry fermentation process, as well as determining the biogas yield, at the Slovak university of Agriculture (SUA) there has been developed an experimental device enabling the pilot plant trials, which is installed at the biogas station within the area of the VPP SPU Ltd. in Kolínany. A pilot plant experiment of biogas production based on Miscanthus $\times$ giganteus (Miscanthus sinensis Anderss.) phytomass within dry fermentation process was carried out at the period from 25 February to 25 March 2013. The monitored production of biogas was based on the substrate mixture of components formed as follows: the biomass from preceding cycle (farmyard manure) and ensilage from Miscanthus phytomass. In these experiments the amount of produced biogas, analysis of biogas and the input substrate were materialized by standard methodology. On base of the obtained results, we can formulate the conclusion: the tested substrate mainly consists of Miscanthus phytomass and manure was suitable for biogas production technology and anaerobic dry fermentation process. The yield of Miscanthus substrate in our experiments was around 117 litres of biogas per $1 \mathrm{~kg}$ of dry matter silage. For assurance of the continuity and uniformity in the production of biogas by dry fermentation process, the multiple-fermentation chamber is needed, which must be saturated gradually with dosing interval. This dosing interval is caused by residence time and the number of chambers. For example, at the residence time of 28 days and 4 chambers, the need of the substrate change will be on weekly base in each chamber.
\end{abstract}

Keywords: Miscanthus $\times$ giganteus, biogas, farmyard manure, silage, dry fermentation, biogas yield

Anaerobic fermentation of wet organic feedstock with capturing biogas can be classified as low potential energy resource. Such technologies contribute to the reduction of GHG emissions from organic residues of all kinds at their current exploitation within energy sector. Dry fermentation process allows methanisation of loose biomass from agriculture and municipal bio-residues without conversion of their consistency to the liquid state. Instead, the substrate is maintained in the fermentation chamber spraying the wet fermentation solution (percolate) circulating in a closed cycle (Jandačka and Malcom, 2007).

Biogas production by anaerobic decomposition of organic matter is not only an efficient way of obtaining energy from animal or plant biomass, but also an environmental solution for the disposal of biological residues from agricultural, industrial and food sectors. In the agricultural area, such as liquid manure dumps, this is one of the largest resources of environment contamination by organic waste. In the case of using the entire estimated potential of livestock manure within Slovakia, it will benefit by biogas production amounted up-to 85.2 million $\mathrm{m}^{3}$ per year. At an average methane concentration of $62.5 \%$, the energy equivalent of that amount is 1,900 TJ per year (Gaduš, 2008). To ensure the necessary level of profitability and return on biogas equipment, in recent time to present several types of biomass fermentation called co-fermentation by cogeneration units. Cogeneration unit is used for combined production of electricity and heat (CHP). It is a way suitable for distributed generation on-site consumption. In market, there are many producers, but cogeneration units and available technology are sustained yet. They are available with outputs from $10 \mathrm{~kW}$ to several MW. Investment costs of cogeneration units are much higher compared to gas boilers (Janíček et al., 2010; 2007).

For efficient energy use, especially of biodegradable municipal residues, as well as ensilage of energy plants (with dry matter content until 50\%) there is a very promising process of dry fermentation. The advantage of this process use is the simple structure of the device which does not require energy-intensive stirring and pumping of the substrates, which significantly reduces the need of energy for operation. The decisive factors for the cultivation and exploitation of energy crops are the price production of phytomass as a biofuel or raw materials for biofuel - 
biomethane production, and the production cost. Currently, there are still many practical experiences and economic knowledge missing for the purpose of targeted energy crops to be massively implemented in the agriculture sector. In Slovakia, farmers have already had first experience with the cultivation of Miscanthus, which is particularly appropriate for maize substitution (Porvaz et al., 2008; Jamriška and Surovčík, 2007; Baráková, 2007).

\section{Material and methods}

For detecting the suitability of biomass use for the production of biogas by dry fermentation process, as well as for determining the biogas yield of different substrates based on mixtures of energy crops and organic agriculture residual materials, an experimental device enabling the pilot plant trials has been developed at the SUA and installed at biogas plants within areal of the VPP SPU Ltd. in Kolíñany.

The double wall has a cylindrical shape with a bioreactor volume of 80 litres. The casing of the vessel is embedded heating element, which is connected to the control unit and the temperature control device to enable control and adjustment of the digital temperature ranges in the fermenter. The container is closed by a gas-tight cover, which is situated on the thermometer showing the actual temperature within the fermenter. The bottom of the container has a conical shape with the mouth into the receiver, where it is recycled by pump percolate through the nozzle back into the fermentation vessel. Analysis of biogas was made by equipment MADUR GA 21 and at regular intervals, the basic chemical composition of biogas $\left(\mathrm{CH}_{4}, \mathrm{CO}_{2}, \mathrm{H}_{2} \mathrm{~S}\right.$ and $\left.\mathrm{O}_{2}\right)$ is determined. Moreover, it regularly measures the amount of biogas produced. The substrate prior to dosing and at the end of the fermentation is carried out and the chemical analysis of the biomass.

The field trial was carried out in 2012 and it was carried out within the district of Milhostov, where there is an experimental-working place of the NAFC - Agroecology research Institute Michalovce. Permanent herbaceous energy crops, among which was the silver grass Miscanthus $\times$ giganteus, were grown on Gleyic Fluvi-soils at natural conditions without irrigation.

The determination of the dry matter content of $30-38 \%$ above ground phytomass Miscanthus was the main observed factor. Harvest was realized at a dry matter content of $33 \%$, a mass was adjusted to a length of chop 1.5 to $2 \mathrm{~cm}$ and oppressed no air in the 60 litres plastic containers without preservatives.

Before filling the fermenter a mixture consisting of Miscanthus silage in an amount of $28 \mathrm{~kg}$ thoroughly was mixed with $20.1 \mathrm{~kg}$ enzymes (farmyard straw manure from the previous fermentation cycle). The percolate for wetting the biomass was removed from the fermenter biogas plant in the amount of 5 litres with the following parameters:

- dry matter content of $6.4 \%$,

- $\mathrm{pH} 7.3$, temperature of $39.2^{\circ} \mathrm{C}$,

- mixed with the original 3 litres in volume.

Chemical analysis on the biomass before and after fermentation were determined as follows:

- chemical oxygen demand COD $\left(\mathrm{mg}^{-1}\right)$ - photometry,

- the sulphate content $\mathrm{SO}_{4}^{2-}\left(\mathrm{mg} \mathrm{l}^{-1}\right)$ photometry,

- total nitrogen content $\mathrm{Nt}\left(\mathrm{mg} \mathrm{l}^{-1}\right)$ photometry,
- dry matter content of \% SH (\%) - by gravimetric weights.

Components of biogas measured by gas analyser MADUR were determined as follows:

- methane $\mathrm{CH}_{4}$ (\% vol.) - dual-beam infrared sensor,

- carbon dioxide $\mathrm{CO}_{2}$ (\% vol.) - dualbeam infrared sensor,

- oxygen $\mathrm{O}_{2}$ (\% vol.) - electrochemically, - $\mathrm{H}_{2} \mathrm{~S}$ (ppm vol.) - electrochemically.

Pilot-scale experiments with application of dry fermentation process for the production of biogas were realized during the period from 25 February to 25 March 2013. The production of biogas from a mixture of biomass from the previous cycle (manure) and Miscanthus silage were monitored. During observations there were determined quantity of produced biogas, qualitative bio-gas analysis and the input substrate (by standard methodology). Throughout the cycle they were evaluated daily, in particular: production of biogas in terms of litre per day, biogas composition and $\mathrm{pH}$ percolate.

\section{Results and discussion}

The advantage of the dry fermentation process is so called rate process of performance, when the substrate is filled into the fermenter and for

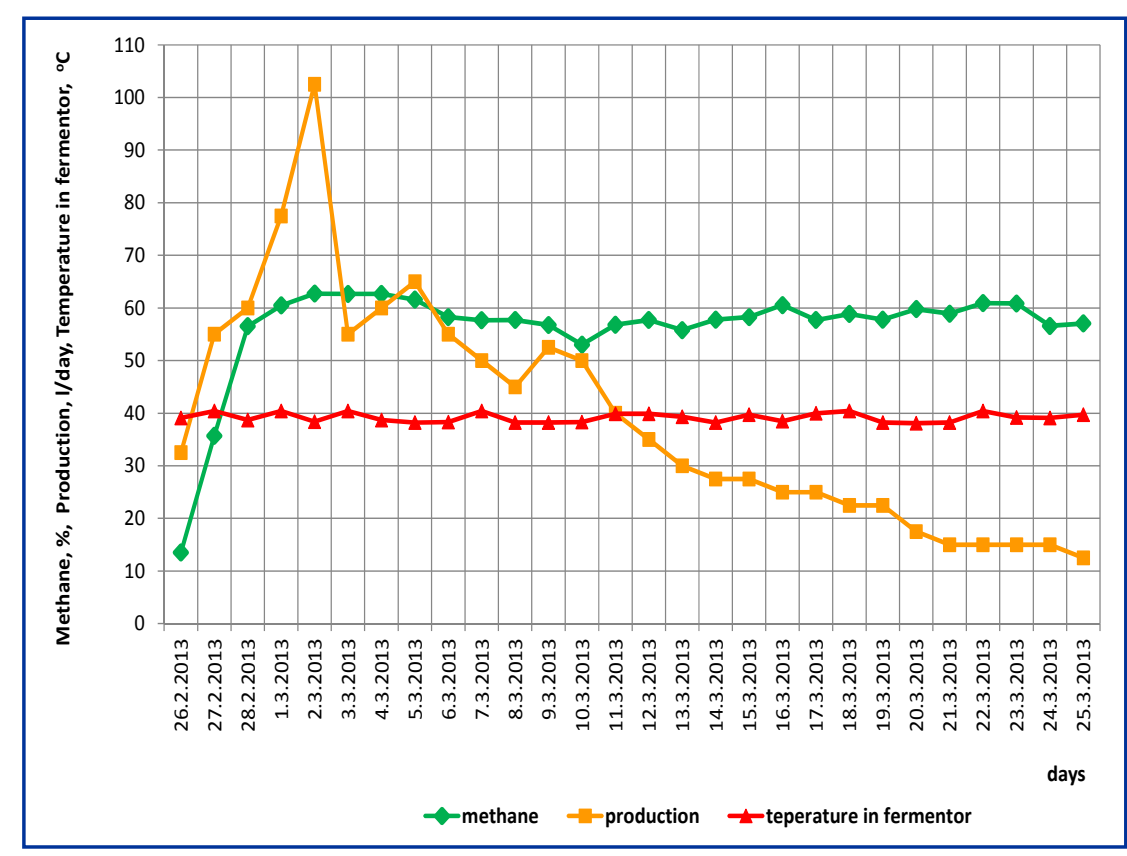

Figure 1 The course of biogas production and methane content during fermentation of mixed substrate 


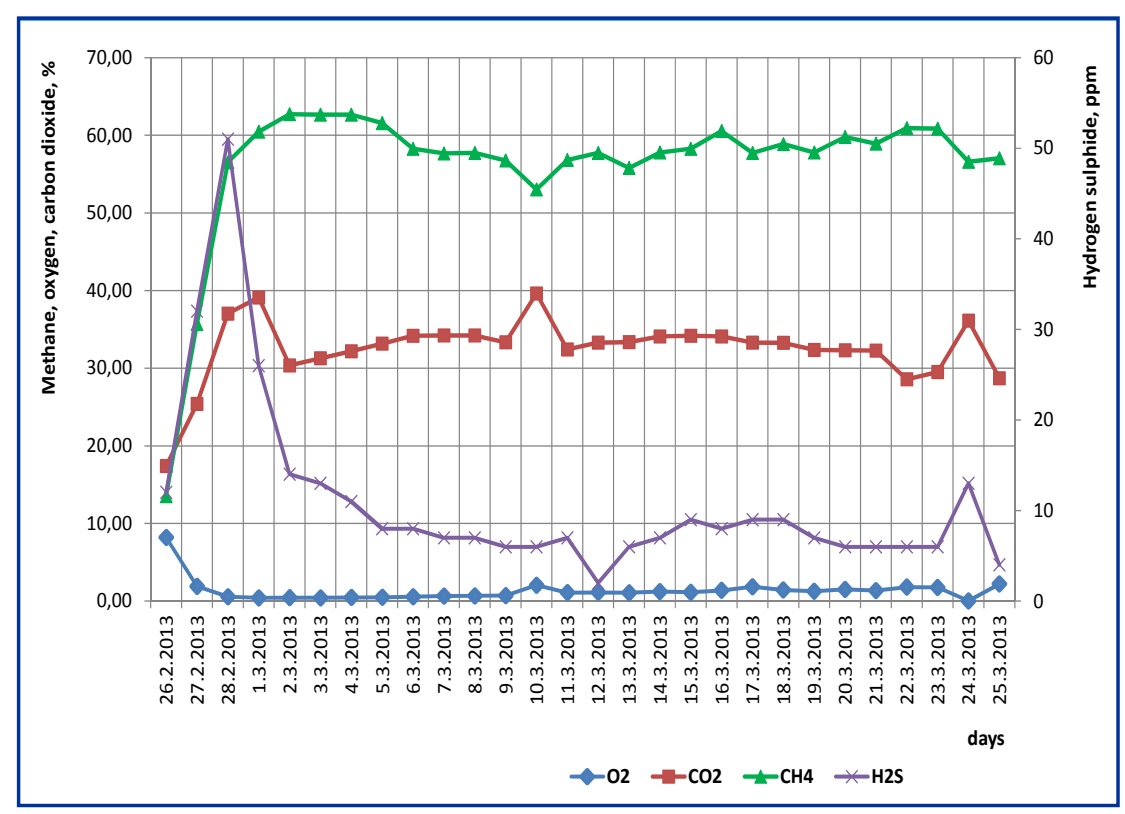

Figure 2 The course of methane, carbon dioxide, oxygen and hydrogen sulphide in biogas

the entire residence time it is not completed. Biomass is only a sprinkling of percolate which is at the start added from an external source, but during the operation at the own status as a substrate. In this way, a very short rise time of the fermentation process is achieved, as seen in the graph in Figure 1 , which has the fourth day the content of $56.52 \%$ methane. On the fifth day, the value of methane was higher than $60 \%$, and those values were achieved almost during the entire experimental period. The highest methane content more than $62 \%$ was achieved from the sixth to eighth day of the experiment. During the whole cycle lasting 29 days, there were produced 1,105 litres of biogas. Biogas composition was analysed by MADUR apparatus and course of the values of individual components of biogas can be seen in Figure 1 and Figure 2. From the Figure 2 it is clear that during fermentation the tested substrate showed a low level of hydrogen sulphide production, 10.92 ppm on average. This biogas would not be necessary after to application as a fuel in a gas engine to edit.

The temperature of the fermenter was maintained at highly stable levels, $39.16^{\circ} \mathrm{C}$ on average, and the $\mathrm{pH}$ was 7.51 in average. Before loading into the fermenter, dry matter content of the substrate reached $33.57 \%$ on average, and the organic material degradability displayed values reaching 94.23\% at maximum. Average values of the monitored parameters are shown in Table 1 and Table 2.

During the whole testing period the composition of biogas was monitored by the gas analyser. Summary obtained mean values of the percentage presence of the set of Table 2.

\section{Conclusions}

For detecting the suitability of Miscanthus $\times$ giganteus phytomass for

Table 1 The mean values of monitored parameters and chemical composition of substrates

\begin{tabular}{|c|c|c|}
\hline Parameter & Base unit & Composition of substrate \\
\hline pH & - & 4.799 \\
\hline temperature & ${ }^{\circ} \mathrm{C}$ & 30.4 \\
\hline TS & $\%$ & 33.57 \\
\hline vSS & $\%$ & 31.54 \\
\hline OTS & $\%$ TS & 94.23 \\
\hline COD & $\mathrm{mg} \mathrm{l}^{-1}$ & 125500 \\
\hline VFA & $\mathrm{mg} \mathrm{l}^{-1}$ & 4000 \\
\hline The equivalent of acetic acid & $\mathrm{mg} \mathrm{l}^{-1}$ & 2000 \\
\hline $\mathbf{N}_{\mathrm{t}}$ & $\mathrm{mg} \mathrm{l}^{-1}$ & 9540 \\
\hline $\mathrm{SO}_{4}$ & $\mathrm{mg} \mathrm{l}^{-1}$ & 759 \\
\hline
\end{tabular}

Table 2 The mean values of monitored parameters - cycle from 4th to 29th day

\begin{tabular}{|l|c|c|c|c|}
\hline \multirow{2}{*}{ Material/Base unit } & $\mathbf{C H}_{4}$ & $\mathbf{H}_{2} \mathbf{S}$ & $\mathbf{C O}_{2}$ & Biogas production \\
\cline { 2 - 5 } & volumetric \% & $\mathrm{ppm}$ & volumetric \% & I day $^{-1}$ \\
\hline $\begin{array}{l}\text { Substrate fermentation }+ \\
\text { Miscanthus } \times \text { giganteus }\end{array}$ & 58.67 & 10.07 & 33.33 & 39.13 \\
\hline
\end{tabular}

TS - dry matter content; OTS - organic dry matter; VSS - loss on ignition; COD - chemical oxygen demand; $\mathrm{N}_{\mathrm{t}}$ - total nitrogen; $\mathrm{SO}_{4}^{2-}$ - sulphate 
production of biogas by dry fermentation process, as well as to determine the biogas yield, an experimental device enabling the pilot plant trials has been developed at the SUA, which is installed at biogas station within the areal of the VPP SPU Ltd. in Kolíňany.

A pilot plant experiment with the dry fermentation process of Miscanthus phytomass for biogas production was carried out from 25 February to 25 March 2013. The production of biogas was monitored from a mixture as follows: the biomass from preceding cycle (farmyard manure) and ensilage from Miscanthus phytomass.

In these experiments, the amount of produced biogas, analysis of biogas and the input substrate were realized by standard methodology. As it is apparent from obtained results, the tested biomass consisting of Miscanthus is suitable for biogas production technology by dry anaerobic fermentation. Yield of Miscanthus phytomass in our experiments was around 117 litres of biogas from $1 \mathrm{~kg}$ of dry matter silage.
JAMRIŠKA, P. - SUROVČíK, J. 2007. Rastlinná výroba zdroj obnovitel'nej energie. In Biomasa pre regionálnu energetiku. Nitra : SPU, 2007, s. 66-70. ISBN 978-80-8069-892-8.

JANDAČKA, J. - MALCHO, M. 2007. Biomasa ako zdroj energie. Žilina, 2007. ISBN 978-80-969161-4-6.

JANÍČEK, F. - DARUL'A, I. - GADUŠ, J. - REGULA, E. - SMITKOVÁ, M. - POLONEC, L. - L'UDVÍK, J. - KUBICA, J. 2007. Obnovitel'né zdroje energie 1. Technológie pre udržatel'nú budúcnost'. Bratislava : STU, 2007. 176 s. ISBN 978-80-969777-0-3.

JANÍČEK, F. - GADUŠ, J. - ŠÁLY, V. - DARULA, I. - REGULA, E. - SMITKOVÁ, M. - KUBICA, J. - PÍPA. M. - BINDZÁR, M. 2010. Obnovitel'né zdroje energie 2. Perspektívne premeny a technológie. Bratislava : STU, 196 s. ISBN 978-80-89402-13-7.

GADUŠ, J. 2008. Bioplyn - jeho výroba a využitie v podmienkach Slovenska. Nitra : SPU, 2008.

PORVAZ, P. - MATI, R. - KOTOROVÁ, D. - JAKUBOVÁ, J. 2008. Pestovanie ozdobnice čínskej (Miscanthus sinensis Anderss.) na energetické účely: Metodická príručka. Michalovce : SCPV - ÚA, 2008, 32 s. ISBN 978-80-88872-93-1.

\section{References}

BARÁKOVÁ, A. 2007. Slama ako energeticky priaznivý zdroj biomasy z pol'nohospodárstva. In Biomasa pre regionálnu energetiku. Nitra : SPU, 2007, s. 24-35. ISBN 978-80-8069-892-8. 